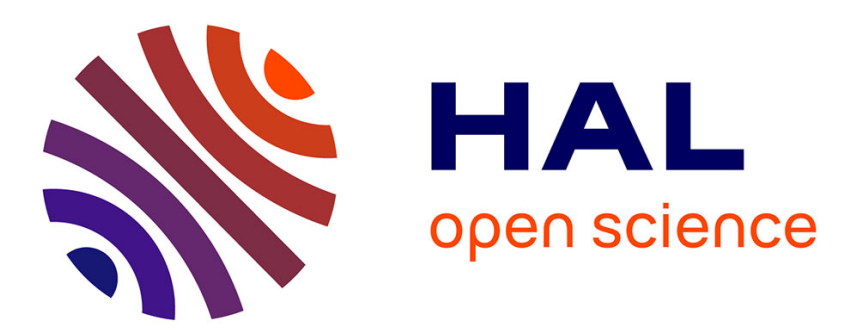

\title{
Optimal Design of a PV/Fuel Cell Hybrid Power System for the City of Brest in France
}

Omar Hazem Mohammed, Yassine Amirat, Mohamed Benbouzid, Adel Elbast

\section{To cite this version:}

Omar Hazem Mohammed, Yassine Amirat, Mohamed Benbouzid, Adel Elbast. Optimal Design of a PV/Fuel Cell Hybrid Power System for the City of Brest in France. IEEE ICGE 2014, Mar 2014, Sfax, Tunisia. pp.119-123. hal-01023490

\section{HAL Id: hal-01023490 https://hal.science/hal-01023490}

Submitted on 13 Jul 2014

HAL is a multi-disciplinary open access archive for the deposit and dissemination of scientific research documents, whether they are published or not. The documents may come from teaching and research institutions in France or abroad, or from public or private research centers.
L'archive ouverte pluridisciplinaire HAL, est destinée au dépôt et à la diffusion de documents scientifiques de niveau recherche, publiés ou non, émanant des établissements d'enseignement et de recherche français ou étrangers, des laboratoires publics ou privés. 


\section{Optimal Design of a PV/Fuel Cell Hybrid Power System for the City of Brest in France}

\author{
Omar Hazem Mohammed ${ }^{1,2}$, Yassine Amirat ${ }^{2}$, \\ Mohamed Benbouzid ${ }^{1}$ \\ ${ }^{1}$ University of Brest, EA 4325 LBMS, Brest, France \\ ${ }^{2}$ ISEN Brest, EA 4325 LBMS, Brest, France \\ Mohamed.Benbouzid@univ-brest.fr
}

\author{
Adel A. Elbaset ${ }^{3}$ \\ ${ }^{3}$ University of Minia, Electrical Engineering Department, \\ Minia, Egypt \\ Adel.Soliman@mu.edu.eg
}

\begin{abstract}
This paper deals with the optimal design of a stand-alone hybrid photovoltaic and fuel cell power system without battery storage to supply the electric load demand of the city of Brest, Western Brittany in France. The proposed optimal design study is focused on economical performances and is mainly based on the loss of the power supply probability concept.

The hybrid power system optimal design is based on a simulation model developed using HOMER. In this context, a practical load demand profile of Brest city is used with real weather data.
\end{abstract}

Keywords-Hybrid power system, renewable energy, fuel cell, photovoltaic, generation unit sizing, energy cost, HOMER.

\section{INTRODUCTION}

The city of Brest is located in a sheltered position not far from the western tip of the Breton peninsula, and the western extremity of metropolitan France. Providing electricity to this region is becoming a challenging task. Indeed, its energy consumption depends on the "regional sidelines" by highvoltage transmission lines through high-distance with consequent high-line losses, especially during stalling winter peak. In order to tackle this constraint, the city of Brest is adopting some tracks such as reducing its own consumption using other alternative resources, generating savings wherever it is possible, or reporting peak periods and encouraging to consume less during these periods. Despite these solutions, the consumption of the city of Brest is still increasing and reaches $5 \%$ every year: This yield to urge the use of renewable energies. To today the use of renewable sources in energy production is still small compared to non-renewable energy sources such as fuel fossil and nuclear energies. So renewable energy sources must be increased by adopting a hybrid energy source schemes to increase the system reliability and security [1]. One of the most promising hybridization approaches is the combination of PV panels to other resource. Indeed, this is a well-developed technology that can be used in a large scale [2-5]. In addition, battery storage could be needed [6-8]. When the energy storage capacity may be limited, the use of supercapacitors could be a viable solution [9-10]. Renewable energy sources do not provide a constant power, but their complementary combination provides more continuous electrical output and is often supported by storage devices such as batteries to increase the system reliability [11-12]. In case of the renewable sources are not able to cope with the load demand, they can be hybridized with traditional energy sources, such as diesel generators (for stand-alone applications) [13-18].

For control purposes, different strategies based on operating modes and combining technical-economic aspects are considered for the energy management of stand-alone hybrid power systems [1].

For the city of Brest, it is proposed a hybrid power systems using PV generators hydrogen for energy storage purposes. In this case, the hydrogen is produced by an electrolyzer powered by the electrical energy excess from the renewable energy source. The produced hydrogen feeds then a fuel cell (FC) system, which will supply the city of Brest in high-load demand period. Otherwise, it will be used as a secondary source of energy [16-17]. For such king of hybrid power systems, the sources can be optimally sized with different techniques and then selected from commercially available components [1], [19-20].

In this context, the proposed hybrid power system intended to provide electricity for the city of Brest is optimally designed using a HOMER-based study using a practical load demand profile of Brest city is used with real weather data.

The proposed hybrid power system model, which will be implemented in HOMER, is depicted by Fig. 1.

\section{HOMER SOFTWARE}

HOMER (Hybrid Optimization Model for Electric Renewable) software has been developed by NREL (National Renewable Energy Laboratory) [21]. It performs hourly simulations of every possible combination of components entered and ranks the systems according to user-specified criteria such as cost of energy (COE) or Capital Costs (CC). HOMER has been extensively used as a sizing and optimization software tool [22].

In this study, where the hybrid power system consists of PV generators, fuel cells, electrolyzer, and a hydrogen tank, HOMER will determine the best feasible power system feasible configuration that can cope with the load demand. The analysis is based on the estimation of the installation cost, the replacement cost, operation and maintenance cost, and so on in addition with high reliability to satisfy the load demand.

The optimization process is done after simulating the entire possible solutions of hybrid power system configurations. 


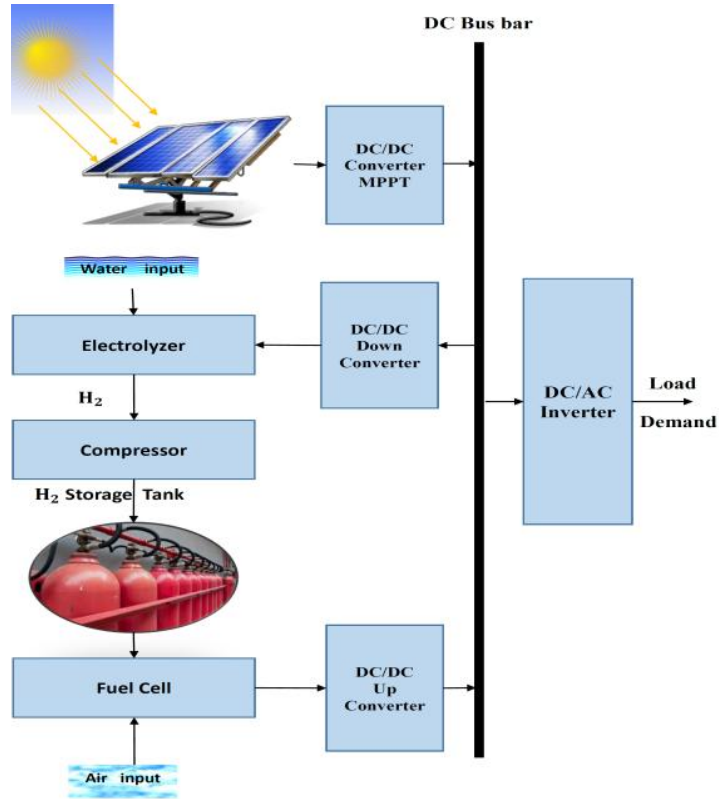

Fig. 1. Schematic of the proposed PV/FC hybrid system.

HOMER displays then a list of configurations sorted based on the Total Net Present Cost (TNPC) that can be used to compare different configurations from the lowest to the highest TNPC. However, TNPC-based system configuration depends on the sensitivity variables (i.e. system constraints, component prices) chosen by the designer. The optimization process is in this context repeated for every sensitivity variables selection.

\section{SYSTEM DESCRIPTION}

The hybrid power system design depends on some important sensitivity variables to optimize the system cost and the component sizes. Hence, before designing the system model, parameters like solar irradiation, location, and load demand have to be evaluated.

\section{A. Case Study}

The proposed hybrid power system for the city of Brest is tested using a practical load demand profile with real weather data: The latitude and longitude for location $\left(48,45^{\circ} \mathrm{N}\right.$ latitude, $-4,42^{\circ} \mathrm{E}$ longitude). The project estimated lifetime is about 25 years while the annual interest rate is fixed to $6 \%$.

\section{B. Electrical Load Profile}

The city of Brest load demand is illustrated by Figs. 2 and 3 . The city load has been scaled to $16000 \mathrm{kWh} /$ day. Seasons scale peak load is taken as $2 \mathrm{MW}$. It should be noted that the 2MW annual peak load occurs in January. The largest demand occurs during the peak season (between December and January) and the lowest demand happens during the low season (between July and September).

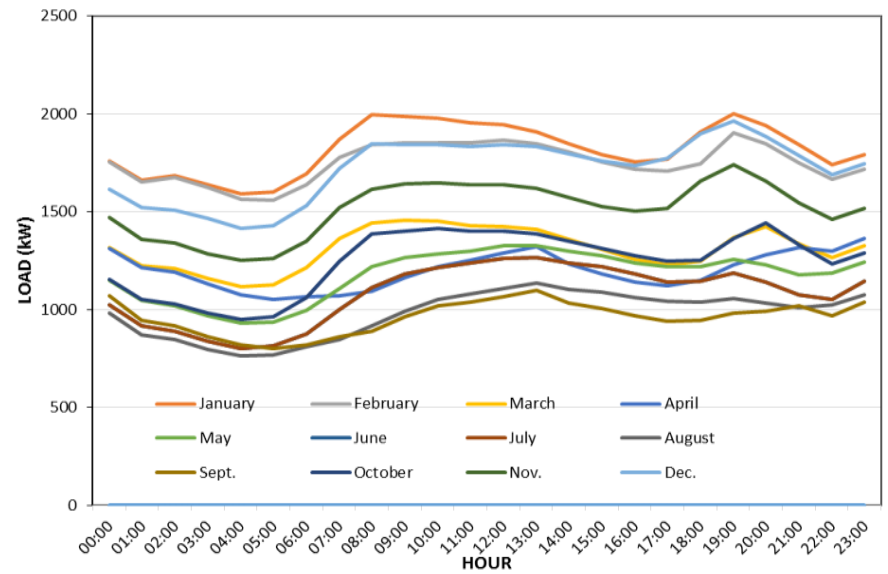

Fig. 2. Hourly average load variations in a year for all months.

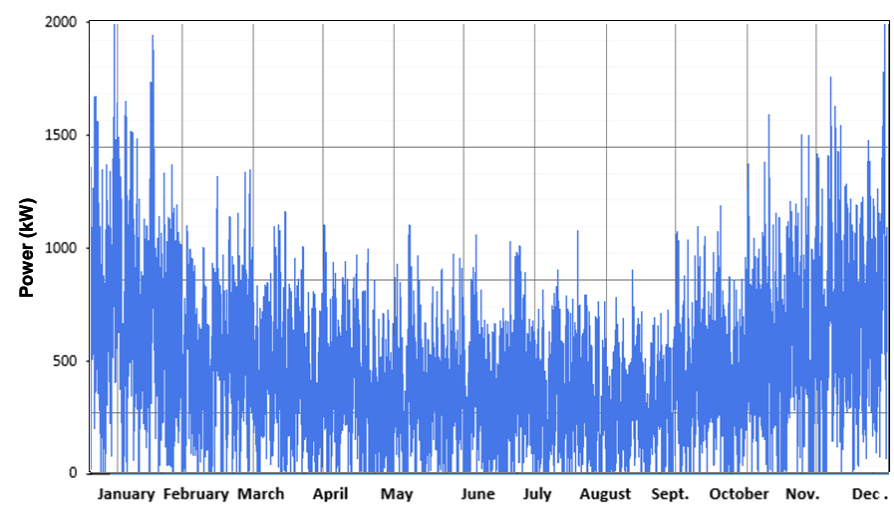

Fig. 3. Daily average load for a complete year.

\section{Solar Resource and PV Generator Data}

For the city of Brest, solar radiation data were obtained from the NASA Atmospheric Data Center [22]. Figure 4 depicts the solar radiation profile over a one-year period. The annual average solar radiation for this area is about 3.39 $\mathrm{kWh} / \mathrm{m}^{2} /$ day.

Regarding the PV generator, the array slope angle is set to $49^{\circ}$ and the array azimuth is $0^{\circ}$ which is referring to the south direction. The lifetime for this PV array system is 25 years with a de-rating factor of $70 \%$ and a ground reflectance is $20 \%$.

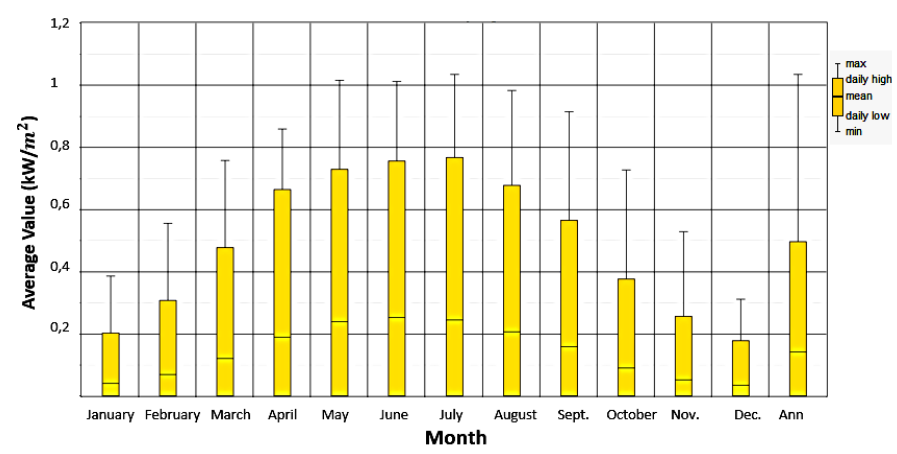

Fig. 4. Monthly average daily solar radiation. 
The PV plant effect of temperature is considered. The clearness index and average the solar radiation are given in Table 1.

\section{HYBRID SYSTEM MODELING AND OPERATIONAL CONTROL STRATEGY}

\section{A. Hybrid System Modeling}

Even if the city of Brest receives a small amount of solar radiation throughout the year as shown by Fig. 4, this is enough to generate electric power. A hybrid power system that consists of a PV generator with an FC system fed by hydrogen is therefore a feasible solution. In addition, it should be noted that FCs with hydrogen tank are used in off-grid hybrid power systems.

Figure 5 shows the HOMER model of the studied PV/FC hybrid power system.

The optimization process consists in determining the optimal value of a so-called decision variable chosen by the designer and over which he has optimal control and for which HOMER can consider multiple possible values in its optimization process. In this study, decision variables include:

- The PV array size;

- The FC size;

- The DC/AC converter size;

Table 1. Clearness IndeX And Average Solar RADiATION.

\begin{tabular}{|c|c|c|}
\hline Month & Clearness index & $\begin{array}{c}\text { Average radiation } \\
\left(\mathbf{k W h} / \mathbf{m}^{\mathbf{2}} / \mathbf{d a y}\right)\end{array}$ \\
\hline Jan. & 0.332 & 0.950 \\
\hline Feb. & 0.378 & 1.630 \\
\hline March & 0.443 & 2.890 \\
\hline April & 0.509 & 4.550 \\
\hline May & 0.532 & 5.730 \\
\hline June & 0.522 & 6.040 \\
\hline July & 0.525 & 5.850 \\
\hline Aug. & 0.516 & 4.960 \\
\hline Sept. & 0.518 & 3.800 \\
\hline Oct. & 0.433 & 2.150 \\
\hline Nov. & 0.390 & 1.240 \\
\hline Dec. & 0.331 & 0.810 \\
\hline
\end{tabular}

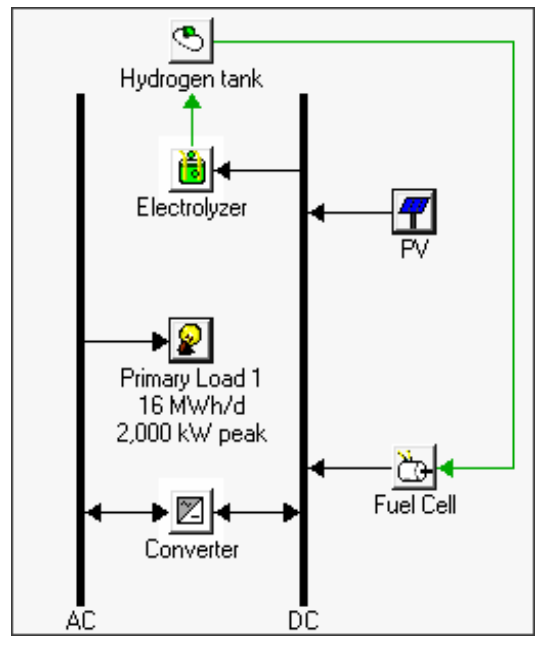

Fig. 5. PV-FC hybrid power system.
- The electrolyzer and hydrogen storage tank sizes.

The annual electrical load must be met by the hybrid power system with a $100 \%$ rate. The considered annual real interest rate is $0.2 \%$. The real interest rate is equal to the nominal interest rate minus the inflation rate. The project lifetime is 25 years.

The model constraints include:

- Maximum annual capacity shortage is $0 \%$;

- Operating reserve is considered to be $10 \%$ of the hourly load.

HOMER input data are given by Tables 2 and 3 [23-25].

\section{B. Operational Control Strategy}

The operational control strategy (power management) is summarized by the following steps:

- In normal operation, the PV generator supplies the load demand. The power excess will be used to feed the electrolyzer for hydrogen production and storage in the tank. If the hydrogen tank is full, the power will be diverted to a dump load.

- If the PV generator power is less than the load demand, FCs will generate the remaining power to supply the load demand. FCs should fully supply the load demand in case of no radiation.

\section{OPTIMIZATION RESULTS}

The HOMER-based optimization of the PV/FC hybrid system using the TNPC is summarized by Table 4 . The achieved configuration should supply power to the city of Brest and is able of meeting its load demand continuously throughout the year.

Table 2. INPUT DATA ON OPTION COSTS.

\begin{tabular}{|c|c|c|c|}
\hline Options & Capital cost & $\begin{array}{c}\text { Replacement } \\
\text { cost }\end{array}$ & O\&M cost \\
\hline PV & $50,000 \$ / 100 \mathrm{~kW}$ & $50,000 \$$ & $5 \$ / \mathrm{yr}$ \\
\hline Fuel Cell & $3,000 \$ / 5 \mathrm{~kW}$ & $2,500 \$$ & $0.08 \$ / \mathrm{h} / \mathrm{kW}$ \\
\hline Converter & $2,000 \$ / 50 \mathrm{~kW}$ & $200 \$$ & $100 \mathrm{O} \& \mathrm{M} \$ / \mathrm{yr}$ \\
\hline Electrolyzer & $1,000 \$ / 10 \mathrm{~kW}$ & $100 \$$ & $10 \$ / \mathrm{yr}$ \\
\hline Hydrogen & $1,000 \$ / 2,000 \mathrm{~kg}$ & $100 \$$ & $10 \$ / \mathrm{yr}$ \\
\hline
\end{tabular}

Table 3. INPUT DATA ON OPTION SIZING AND OTHER PARAMETERS.

\begin{tabular}{|c|c|c|c|}
\hline Options & $\begin{array}{c}\text { Options on size } \\
\text { and unit numbers }\end{array}$ & Life & $\begin{array}{c}\text { Other } \\
\text { information }\end{array}$ \\
\hline PV & $\begin{array}{c}0,3,000,4,200,4,300, \\
4,500,5,000,6,000, \\
8,000 \mathrm{~kW}\end{array}$ & $25 \mathrm{yrs}$ & $\begin{array}{c}\text { De-rating factor } \\
75 \%\end{array}$ \\
\hline Fuel Cell & $\begin{array}{c}0,2,000,2,100 \\
2,200 \mathrm{~kW}\end{array}$ & $40,000 \mathrm{hrs}$ & $\begin{array}{c}\text { Min. load ratio } \\
1 \%\end{array}$ \\
\hline Converter & $\begin{array}{c}0,2,000,2,050 \\
2,100 \mathrm{~kW}\end{array}$ & $20 y r s$ & $\begin{array}{l}\text { Inverter efficiency } \\
95 \%\end{array}$ \\
\hline $\begin{array}{l}\text { Electrolyze } \\
\mathrm{r}\end{array}$ & $\begin{array}{l}0,3,400,3,500 \\
3,600,3,700 \mathrm{~kW}\end{array}$ & $15 \mathrm{yrs}$ & Efficiency $80 \%$ \\
\hline Hydrogen & $\begin{array}{l}0,955,000,955,500 \\
955,600,956,000 \mathrm{~kg}\end{array}$ & $20 \mathrm{yrs}$ & $\begin{array}{c}\text { Initial tank level } \\
10 \%\end{array}$ \\
\hline
\end{tabular}


Table 4. Optimization Results of THE Hybrid PV-FC MOdEL.

\begin{tabular}{|c|c|}
\hline PV $(\mathrm{kW})$ & 4200 \\
\hline FC $(\mathrm{kW})$ & 2000 \\
\hline Converter $(\mathrm{kW})$ & 2000 \\
\hline Electrolyzer $(\mathrm{kW})$ & 3400 \\
\hline Hydrogen tank $(\mathrm{kg})$ & 955000 \\
\hline Initial Capital Cost $(\$)$ & $4,197,750$ \\
\hline Total NPC $(\$)$ & $8,942,636$ \\
\hline COE $(\$ / \mathrm{kWh})$ & 0.120 \\
\hline Operating cost $(\$ / \mathrm{yr})$ & 371,177 \\
\hline
\end{tabular}

The optimal configuration is found after carrying-out several simulations with a $3.39 \mathrm{kWh} / \mathrm{m}^{2} /$ day solar radiation and an annual average clearness index of 0.452 , and considering different PV, FC, electrolyzer, hydrogen tank, and converter capacities: The PV capacity has been allowed to vary from 0 to $8000 \mathrm{~kW}$, the FC power has been considered to change from 0 to $2200 \mathrm{~kW}$, the electrolyzer and the converter capacities have been allowed to vary from 0 to $2200 \mathrm{~kW}$, the hydrogen storage capacity has been allowed up to $956000 \mathrm{~kg}$. In this context, a load-following control strategy was used.

The achieved hybrid power system TNPC is $8,942,636 \$$ while its capital cost and cost of energy (COE) are 4,197,750\$, $0.120 \$ / \mathrm{kWh}$, respectively for one year. Figure 6 , Tables 5 and 6 summarize the proposed power system different costs. In terms of power, Fig. 7 shows the monthly average power production of each renewable source. In addition, Tables 7 and 8 give the annual electric energy production and consumption, respectively. In addition, Table 9 gives the hybrid power system annual emissions.

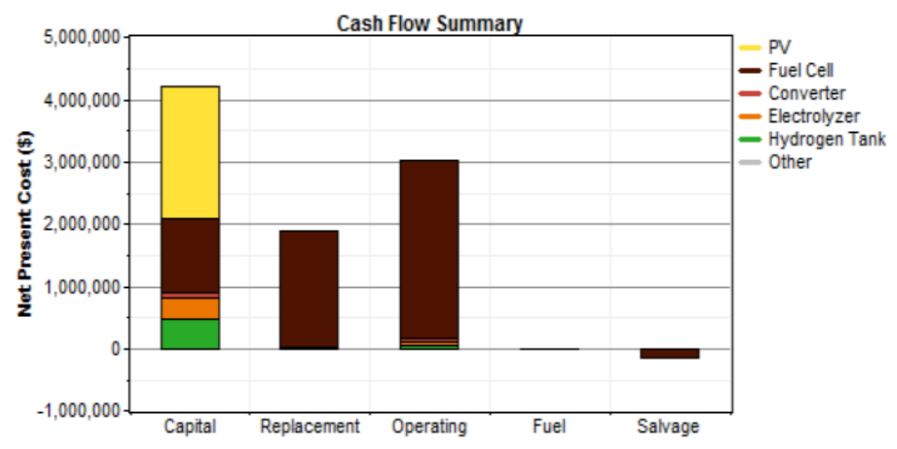

Fig. 6. Cost summary of the PV/FC hybrid system.

Table 5. Net PRESENT COSTS OF THE HyBRID SySTEM.

\begin{tabular}{|c|c|c|c|c|c|}
\hline \multirow{2}{*}{ Comp. } & Capital & Replace. & O\&M & Salvage & Total \\
\cline { 2 - 7 } & $\mathbf{( \$ )}$ & $\mathbf{( \$ )}$ & $\mathbf{( \$ )}$ & $\mathbf{( \$ )}$ & $\mathbf{( \$ )}$ \\
\hline PV & $2,100,000$ & 0 & 2,685 & 0 & $2,102,685$ \\
\hline Fuel Cell & $1,200,000$ & $1,859,515$ & $2,856,11$ & $-148,24$ & $5,767,379$ \\
\hline Converter & 80,000 & 2,494 & 51,133 & $-1,398$ & 132,230 \\
\hline Electrol. & 340,000 & 14,187 & 43,463 & $-2,641$ & 395,010 \\
\hline H2 Tank & 477,500 & 14,889 & 61,041 & $-8,344$ & 545,085 \\
\hline Other & 250 & 0 & 0 & 0 & 250 \\
\hline System & $4,197,750$ & $1,891,085$ & $3,014,43$ & $-160,62$ & $8,942,64$ \\
\hline
\end{tabular}

Table 6. AnNuAlized Costs of THE HyBRID System.

\begin{tabular}{|c|c|c|c|c|c|}
\hline Component & Capital & Replace. & O\&M & Salvage & Total \\
& $\mathbf{( \$ / y r )}$ & $\mathbf{( \$ / y r )}$ & $\mathbf{( \$ / y r )}$ & $\mathbf{( \$ / y r )}$ & $\mathbf{( \$ / y r )}$ \\
\hline PV & 164,276 & 0 & 210 & 0 & 164,486 \\
\hline Fuel Cell & 93,872 & 145,464 & 223,424 & $-11,597$ & 451,163 \\
\hline Converter & 6,258 & 195 & 4,000 & -109 & 10,344 \\
\hline Electrol. & 26,597 & 1,110 & 3,400 & -207 & 30,900 \\
\hline H2 Tank & 37,353 & 1,165 & 4,775 & -653 & 42,640 \\
\hline Other & 20 & 0 & 0 & 0 & 20 \\
\hline System & 328,376 & 147,933 & 235,809 & $-12,565$ & 699,553 \\
\hline
\end{tabular}

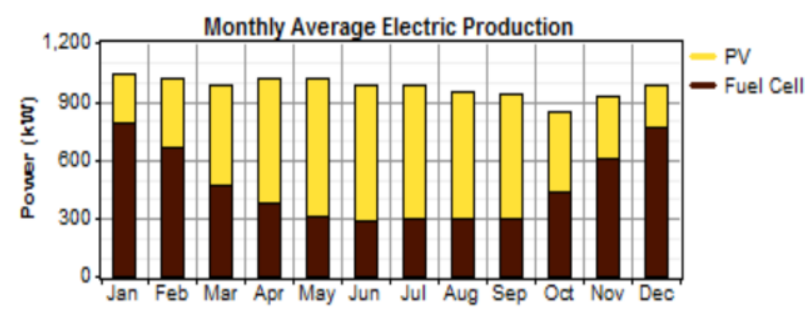

Fig. 7. Monthly average electric production.

Table 7. AnNuAl Electric ENERgy Production of THE Hybrid SySTEM.

\begin{tabular}{|c|c|c|}
\hline Component & Production(kWh/yr) & Fraction \\
\hline PV array & $4,442,947$ & $52 \%$ \\
\hline Fuel Cell & $4,070,915$ & $48 \%$ \\
\hline Total & $8,513,862$ & $100 \%$ \\
\hline
\end{tabular}

Table 8. ANNUAL ElECTRIC ENERGy CONSUMPTION.

\begin{tabular}{|c|c|c|}
\hline Load & Consumption $(\mathbf{k W h} / \mathbf{y r})$ & Fraction \\
\hline AC primary load & $5,839,835$ & $71 \%$ \\
\hline Electrolyzer load & $2,366,666$ & $29 \%$ \\
\hline Total & $8,206,500$ & $100 \%$ \\
\hline
\end{tabular}

Table 9. ANNUAL EMISSIONS OF THE HYBRID SYSTEM.

\begin{tabular}{|c|c|}
\hline Pollutant & Emissions (kg/yr) \\
\hline Carbon dioxide & $-1,390$ \\
\hline Carbon monoxide & 885 \\
\hline Unburned hydrocarbons & 98 \\
\hline Particulate matter & 66.7 \\
\hline Sulfur dioxide & 0 \\
\hline Nitrogen oxides & 7,893 \\
\hline
\end{tabular}

Finally, Figs. 8 and 9, which show the annual operation output of the PV and the FC generator, respectively, are given to illustrate the operational control strategy according to the city of Brest load demand and weather data.

\section{CONCLUSION}

This paper dealt with the optimal design of a stand-alone hybrid PV/FC power system without battery storage to supply the electric load demand of the city of Brest, Western Brittany in France. The proposed optimal design study was focused on economical performance and was mainly based on the loss of the power supply probability concept. 


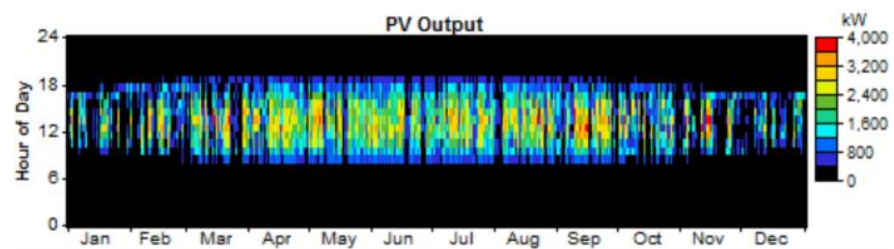

Fig. 8. Annual PV generator operation.

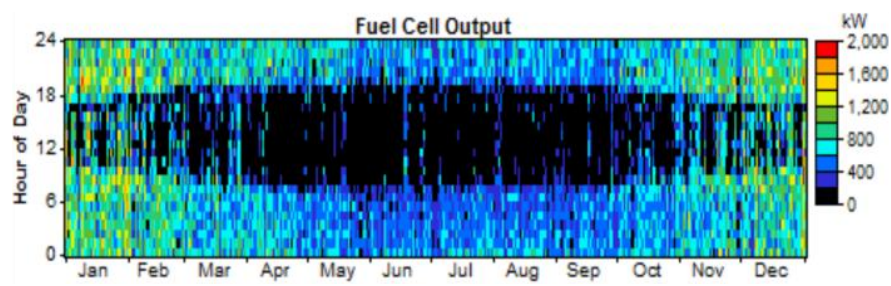

Fig. 9. Annual fuel cell generator operation.

The HOMER-based optimization study using the total net present cost has clearly shown that the proposed hybrid power system and in particular fuel cells are a viable alternative to diesel generators as a non-polluting reliable energy source with a reduced total cost of maintenance. It has also been shown that a fuel cell generator could efficiently complement a fluctuating renewable source as solar energy to satisfy growing loads.

\section{REFERENCES}

[1] O.H. Mohammed, Y. Amirat, M.E.H. Benbouzid and T. Tang, "Hybrid generation systems planning expansion forecast: A critical state of the art review", in Proceeding of the 2013 IEEE IECON, Vienna (Austria), pp.1666-1671, November 2013.

[2] F.H. Abanda, J.H.M. Tah, D. Duce, "PV-TONS: A photovoltaic technology ontology system for the design of PV-systems," Engineering Applications of Artificial Intelligence, vol. 26, n 4, pp. 1399-1412, April 2013.

[3] YH. Liu, C.L. Liu, J.W. Huang and J.H. Chen, "Neural-network-based maximum power point tracking methods for photovoltaic systems operating under fast changing environments," Solar Energy, vol. 89, pp. 42-53, March 2013.

[4] K. Himour, K. Ghedamsi and E.M. Berkouk, "Supervision and control of grid connected PV-Storage systems with the five level diode clamped inverter," Energy Conversion and Management, vol. 77, pp. 98-107, January 2014

[5] S. Lizin, S.V. Passel, E. De Schepper and L. Vranken, "The future of organic photovoltaic solar cells as a direct power source for consumer electronics," Solar Energy Materials and Solar Cells, vol. 103, pp. 1-10, August 2012.

[6] S. Semaoui, A.H. Arab, S. Bacha and B. Azoui, "Optimal sizing of a stand-alone photovoltaic system with energy management in isolated areas," Energy Procedia, vol. 36, 358-368, 2013.

[7] Y. Ru, J. Kleissl and S. Martinez, "Exact sizing of battery capacity for photovoltaic systems," European Journal of Control, September 2013.
[8] S. Semaoui, A. Hadj Arab, S. Bacha and B. Azoui, "The new strategy of energy management for a photovoltaic system without extra intended for remote-housing," Solar Energy, vol. 94, pp. 71-85, August 2013.

[9] J. Li, Y. Chen and Y. Liu, "Research on a stand-alone photovoltaic system with a supercapacitor as the energy storage device," Energy Procedia, vol. 16, Part C, pp. 1693-1700, 2012.

[10] M.E. Glavin, P.K.W. Chan, S. Armstrong and W.G. Hurley, "A standalone photovoltaic supercapacitor battery hybrid energy storage system," in Proceedings of the 2008 EPE-PEMC, Poznan (Poland), pp. 16_1695, September 2008.

[11] A. Hiendro, R. Kurnianto, M. Rajagukguk, Y.M. Simanjuntak, Junaidi, "Techno-economic analysis of photovoltaic/wind hybrid system for onshore/remote area in Indonesia," Energy, vol. 59, pp. 652-657, September 2013.

[12] E. Kabalci, "Design and analysis of a hybrid renewable energy plant with solar and wind power," Energy Conversion and Management, vol. 72, pp. 51-59, August 2013.

[13] G. Merei, C. Berger and D.U. Sauer, "Optimization of an off-grid hybrid PV-Wind-Diesel system with different battery technologies using genetic algorithm," Solar Energy, vol. 97, pp. 460-473, November 2013.

[14] A. Colantoni, E. Allegrini, K. Boubaker, L. Longo, S. Di Giacinto and P. Biondi, "New insights for renewable energy hybrid photovoltaic/wind installations in Tunisia through a mathematical model," Energy Conversion and Management, vol. 75, pp. 398-401, November 2013.

[15] R. Kumar, R.A. Gupta and A.K. Bansal, "Economic analysis and power management of a stand-alone wind/photovoltaic hybrid energy system using biogeography based optimization algorithm," Swarm and Evolutionary Computation, vol. 8, pp. 33-43, February 2013.

[16] R. Boudries, "Analysis of solar hydrogen production in Algeria: Case of an electrolyzer-concentrating photovoltaic system," International Journal of Hydrogen Energy, vol. 38, n²6, pp. 11507-11518, August 2013.

[17] D. Rekioua, S. Bensmail and N. Bettar, "Development of hybrid photovoltaic-fuel cell system for stand-alone application," International Journal of Hydrogen Energy, vol. 39, n³, pp. 1604-1611, January 2014.

[18] A.U. Chàvez-Ramirez, V. Vallejo-Becerra, J.C. Cruz, R. Ornelas, G. Orozco, R. Munoz-Guerrero and L.G. Arriaga, "A hybrid power plant (Solar-Wind-Hydrogen) model based in artificial intelligence for a remote-housing application in Mexico," International Journal of Hydrogen Energy, vol. 38, n 6 , pp. 2641-2655, February 2013.

[19] M. Castaneda, A. Cano, F. Jurado, H. Sànchez and L.M. Fernandez, "Sizing optimization, dynamic modeling and energy management strategies of a stand-alone PV/hydrogen/battery-based hybrid system," International Journal of Hydrogen Energy, vol. 38, n¹0, pp. 38303845, April 2013.

[20] B. Panahandeh, J. Bard, A. Outzourhit and D. Zejli, "Simulation of PVwind-hybrid systems combined with hydrogen storage for rural electrification," International Journal of Hydrogen Energy, vol. 36, ${ }^{\circ} 6$, pp. 4185-4197, March 2011.

[21] http://homerenergy.com/

[22] https://eosweb.larc.nasa.gov/sse/

[23] M. Beccali, S. Brunone, M. Cellura and V. Franzitta, "Energy, economic and environmental analysis of RET-hydrogen systems in residential buildings," Renewable Energy, vol. 33, n³, pp. 366-382, March 2008.

[24] S.B. Silva, M.A.G. de Oliveira, M.M. Severino, Economic evaluation and optimization of a photovoltaic-fuel cell-batteries hybrid system for use in the Brazilian Amazon," Energy Policy, vol. 38, n¹1, pp. 67136723, November 2010.

[25] K. Karakoulidis, K. Mavridis, D.V. Bandekas, P. Adoniadis, C. Potolias and N. Vordos, "Techno-economic analysis of a stand-alone hybrid photovoltaic-diesel-battery-fuel cell power system," Renewable Energy, vol. 36, n`8, pp. 2238-2244, August 2011. 